\title{
REVIEW
}

\section{Uncertain future of New England salt marshes}

\author{
Keryn B. Gedan ${ }^{1,2, *}$, Andrew H. Altieri ${ }^{1}$, Mark D. Bertness ${ }^{1}$ \\ ${ }^{1}$ Department of Ecology and Evolutionary Biology, Brown University, Providence, Rhode Island 02912, USA \\ ${ }^{2}$ Present address: Smithsonian Environmental Research Center, Edgewater, Maryland 21037, USA
}

\begin{abstract}
Salt marsh plant communities have long been envisioned as dynamic, resilient systems that quickly recover from human impacts and natural disturbances. But are salt marshes sufficiently resilient to withstand the escalating intensity and scale of human impacts in coastal environments? In this study we examined the independent and interactive effects of emerging threats to New England salt marshes (temperature increase, accelerating eutrophication, consumer-driven salt marsh die-off, and sea level rise) to understand the future trajectory of these ecologically valuable ecosystems. While marsh plant communities remain resilient to many disturbances, loss of critical foundation species and changing tidal inundation regimes may short circuit marsh resilience in the future. Accelerating sea level rise and salt marsh die-off in particular may interact to overwhelm the compensatory mechanisms of marshes and increase their vulnerability to drowning. Management of marshes will require difficult decisions to balance ecosystem service tradeoffs and conservation goals, which, in light of the immediate threat of salt marsh loss, should focus on maintaining ecosystem resilience.
\end{abstract}

KEY WORDS: Climate change $\cdot$ Sea level rise $\cdot$ Salt marsh die-off $\cdot$ Eutrophication $\cdot$ Invasive species · Phragmites australis $\cdot$ Management

Resale or republication not permitted without written consent of the publisher

\section{INTRODUCTION}

Salt marshes are perhaps the most important but misunderstood of the world's major ecosystems. These coastal wetlands have long been valued for their benefits to human society including the provision of food, fuel, building materials, livestock fodder and, more recently, for their ability to filter pollutants, buffer against storms, sequester carbon, and provide aesthetic and recreational opportunities (Gedan et al. 2009). Conservation efforts to preserve the provision of these ecosystem services are based largely on promoting the historic resilience of salt marshes. However, recent research in the western Atlantic, and in New England in particular, where salt marsh conservation science was founded, is revealing ecological interactions and shifts in marsh landscapes that question the fundamental assumptions of marsh resilience. The rules thought to govern salt marsh community structure and stability, based largely on nutrients and physical factors, need to be rewritten to include the unprecedented consumer control and sea level rise, which could interact to override marsh resilience.

\section{HISTORICAL RESILIENCE OF SALT MARSH ECOSYSTEMS}

Historically, salt marshes have been considered resilient to natural and anthropogenic disturbances for several reasons. First, salt marshes are young features by geologic standards, rapidly built by ecosystem engineering plants that trap and bind sediments (Redfield 1965, Niering 1977), which suggests that salt marshes would quickly reform if destroyed. Second, natural disturbances, such as the deposition of wrack (accumulations of dead plant material) and sand on spring and storm tides, are routine in salt marshes (Chapman 1940, Donnelly et al. 2001), and salt marsh vegetation is resilient to these small-scale physical disturbances (Niering 1977). Finally, due to evolutionary adaptations to cope with stressfully anoxic and saline soils, salt marsh plants are uncommonly resistant to many toxic pollutants, such as heavy metals (Weis \& Weis 2004). Historically, these resilient characteristics have allowed salt marsh ecosystems to rebound after extreme impacts from human activities (e.g. Hackensack Meadowlands example in Weis \& Butler 2009). 
However, in the decades since Niering et al. (1977) stressed the resilience of New England salt marsh vegetation dynamics to human activities and natural sealevel fluctuations, it has become apparent that other shallow-water coastal communities, including coral reefs and kelp forests, have been devastated by anthropogenic disturbances (Jackson et al. 2001). In light of persistent human pressure on coastal habitats, we ask in this paper: how will New England salt marshes respond to the multiple, large-scale human impacts they will face over the next century? Niering recognized signatures of anthropogenic impacts in New England salt marshes (Niering et al. 1977, Niering \& Warren 1980), and pioneered the study of how coastal wetlands respond to human activities. Over the past several decades, however, eutrophication, overfishing, and climate change have emerged as global threats to coastal ecosystems (Jackson et al. 2001, Lotze et al. 2006). Can salt marsh plant communities and their provision of ecosystem services persist in the face of accelerating global change? What conservation steps will be necessary to maintain such marsh resilience?

\section{ECOSYSTEM SERVICES OF SALT MARSHES}

Human impacts are concentrated in coastal ecosystems due to a synergism of nearshore human activities, spillover from terrestrial impacts, and the concentration of human settlement along shorelines (UNEP 2006). Although human activities often degrade coastal areas, human populations have long relied heavily on coastal ecosystem services. Estuaries and salt marshes provide more services per unit area than any other ecosystem worldwide (UNEP 2006). Since prehistoric times, marshes have provided edible plants and animals, thatch and fiber for building material, fodder for livestock, and fuel for cooking fires. More recently, marshes have become additionally valued for storm protection (Costanza et al. 2008), biogeochemical filters (Valiela \& Cole 2002), carbon sequestration (Chmura et al. 2003), and as nurseries for commercially harvested fin- and shellfish (Boesch \& Turner 1984). To preserve these functions and their aesthetic and recreational value, many New England marshes have been designated as conservation areas (Bromberg \& Bertness 2005).

\section{HISTORY OF HUMAN IMPACTS ON NEW ENGLAND SALT MARSHES}

Ecologists have long studied ecosystem patterns and processes in New England salt marshes. Pioneering studies of plant succession (Clements 1916), community organization (Chapman 1940), and salt marsh develop- ment (Redfield 1965), as well as advances in community (Bertness 1991) and ecosystem (Valiela \& Teal 1979) ecology were made in New England salt marshes. Thorough understanding of marsh ecosystems developed from dozens of experimental studies and decades of observation should enable us to predict how New England marshes will respond to human impacts more accurately than in regions where scientific information is more limited.

New England salt marshes have sustained centuries of human impacts (Gedan et al. 2009). Some of the first European colonists to New England settled adjacent to salt marshes for their natural treeless pasture and hay products, marine access, and environmental similarity to coastal Europe (Hatvany 2003). Intense clearing of the upland and the resulting eroded sediment promoted rapid marsh expansion, at least in parts of the region (Kirwan et al. 2011). During the American Industrial Revolution, many marshes were tidally restricted by dams, polluted by industrial runoff, intensively ditched for mosquito control, and used for refuse disposal and sewers (Crain et al. 2009). The rarity of salt marsh ponds and waterlogged panne depressions in southern New England is, in part, a historical artifact of intense mosquito ditching (Ewanchuk \& Bertness 2004a).

New England salt marshes have the longest history in North America of outright land conversion (Gedan \& Silliman 2009). Conversion for agriculture, port development, and urbanization has resulted in a $37 \%$ net loss of salt marshes across the region (Bromberg \& Bertness 2005). In 1972 the Clean Water Act regulated dredge and fill activities in salt marshes in the United States. While direct conversion is restricted, New England salt marshes are now assaulted by other continuing, and emerging, human impacts. In the following sections we discuss how predicted increases in temperature, eutrophication, consumer-driven die-offs, and sea level rise may be generating a 'perfect storm' for future New England marsh loss.

\section{TEMPERATURE INCREASE}

Like other temperate ecosystems, salt marshes are predicted to experience substantial temperature increases over the next century (IPCC 2007). In New England, a 2 to $3^{\circ} \mathrm{C}$ increase in average summer air temperature is predicted by mid-century (2035-2064) relative to the 1961-1990 average (Hayhoe et al. 2006). How will increasing temperatures affect salt marsh plant communities? For one effect, temperature can define species ranges, and many recent shifts in species distributions have been correlated with shifts in climate (IPCC 2007). 
Field manipulations of temperature have shown that the climate warming expected over the next century will increase salt marsh plant productivity, confirming predictions based on latitudinal correlations between temperature and productivity (Turner 1976, Kirwan et al. 2009). Mild warming of $<3^{\circ} \mathrm{C}$ with open top chambers in Rhode Island and Maine increased cordgrass Spartina alterniflora productivity by 15 to $45 \%$ (Fig. 1) (Gedan 2009) with similar effects on salt marsh hay S. patens (Gedan \& Bertness 2010). Since Spartina grasses dominate New England marshes, these findings predict there will be increases in ecosystem primary productivity associated with warming over the next century and higher levels of productivity shifting poleward into northern New England (Fig. 1B).

Temperature-driven effects on plant and soil water balance are also important in New England salt marshes. Forb pannes are mid-elevation features of northern New England salt marshes that are sensitive to climate. As-
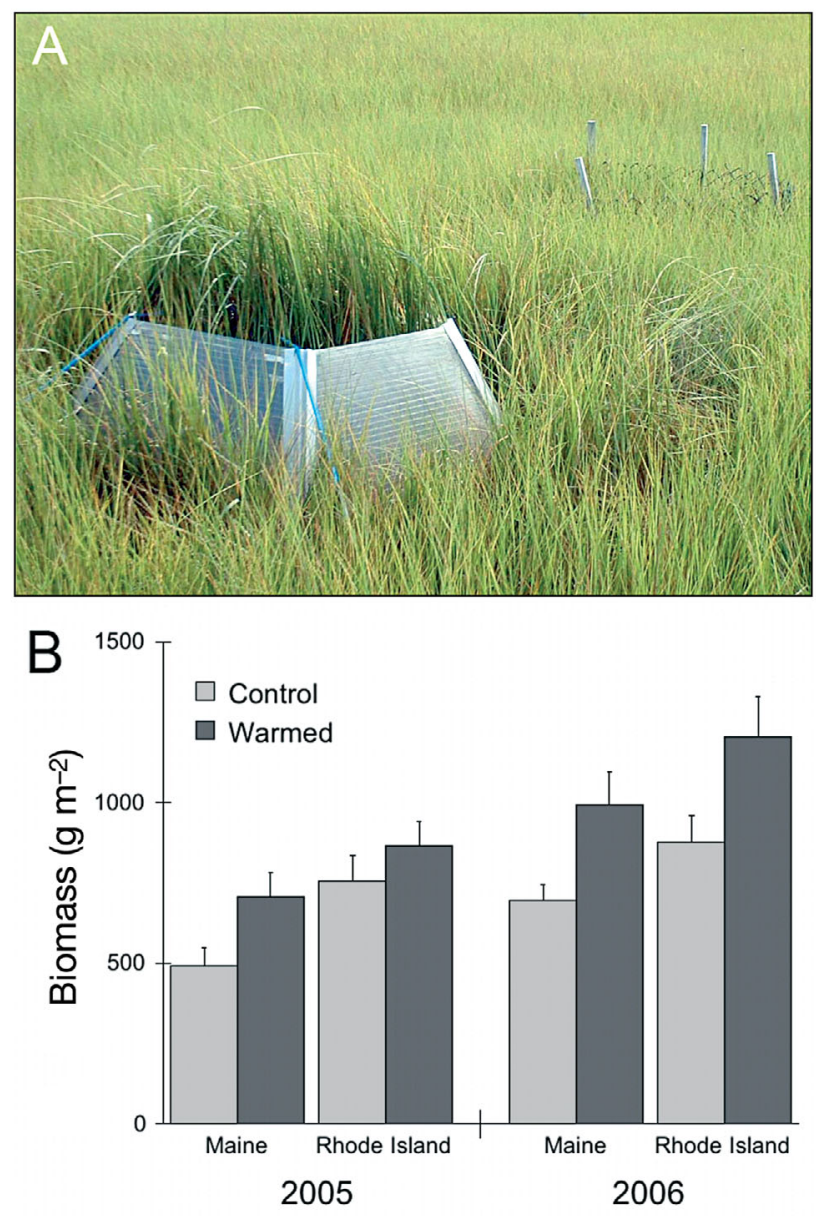

Fig. 1. (A) Warming with passive open top chambers increased Spartina alterniflora aboveground biomass (B) relative to control treatments $( \pm 1 \mathrm{SE})$ at 2 New England sites in 2005 and 2006. See Gedan \& Bertness (2009) for details semblages of halophytic forbs (Fig. 2) occur in these anoxic, waterlogged habitats that provide competitive refuge from clonal marsh grasses (Ewanchuk \& Bertness 2004b). Experimentally increasing temperature in forb pannes increases evapotranspiration and causes forb species to be rapidly outcompeted and displaced by high marsh grasses. These results reveal that temperature increases predicted over the next century will reduce the area of forb panne habitats, driving already rare forb assemblages to local extinction in southern New England and reducing their dominance in northern New England (Fig. 2) (Gedan \& Bertness 2009).
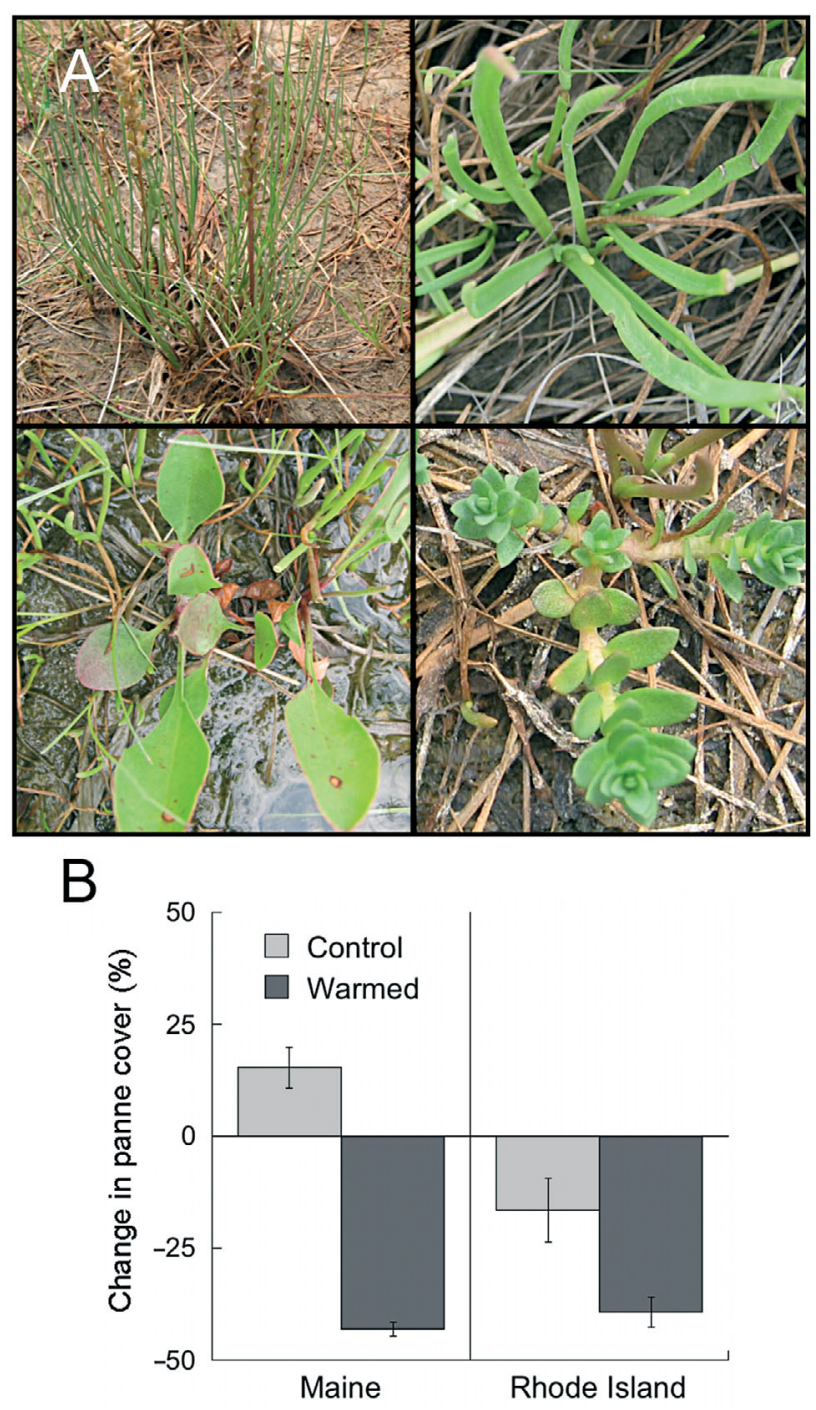

Fig. 2. (A) Salt marsh forb pannes are dominated by a unique assemblage of species, including, clockwise from top left, Triglochin maritima, Plantago maritima, Glaux maritima, and Limonium nashii. (B) Warming with open top chambers reduced the cover of forb panne species by 43 and $39 \%$ relative to baseline conditions in Maine and Rhode Island, respectively ( \pm 1 SE) (see Gedan \& Bertness 2009) 
Beyond shifts in plant productivity and community composition, there may be additional, as yet unknown, effects of climate warming on New England plant communities. For example, temperature-mediated effects on productivity may cascade to other linked ecosystem processes such as decomposition. Temperature increase could also drive range shifts in species that strongly interact with salt marsh plants, such as fiddler crabs (Uca spp.) or the herbivorous crab Sesarma reticulatum, both of whose ranges currently end at the biogeographic barrier of Cape Cod. The effects of temperature increase on these higher level interactions is uncertain. Increases in atmospheric carbon dioxide, the causal driver of temperature increase, could cause additional shifts in plant species composition. In carbon dioxide enrichment experiments, $\mathrm{C}_{3}$ plant species such as the sedge Schoenoplectus americanus replace $\mathrm{C}_{4}$ plant species such as cordgrass and salt marsh hay (Erickson et al. 2007), but it is not clear how concurrent increases in temperature and carbon dioxide will affect species composition.

Due to strong agreement between observed patterns across latitudinal climate gradients and results of experimental warming studies, we are more certain that temperature increase will increase productivity and reduce diversity in New England salt marsh plant communities. Shifts in plant species composition due to increases in warming and carbon dioxide, however, are of less management concern than other impending impacts on marsh plant communities that disable marsh accretion - a process central to the maintenance and persistence of the salt marsh habitat.

\section{EUTROPHICATION}

Eutrophication (nutrient loading) has and will continue to contribute to the shifting structure of New England salt marsh communities. Southern New England estuaries are among the most eutrophic in North America, whereas eutrophication symptoms are largely absent in northern New England estuaries (Bricker et al. 2007). Eutrophication is correlated with population density and land clearing in New England and is driven by sewage inputs to groundwater that are evident in salt marsh food webs (Bannon \& Roman 2008). Although there are plans to reduce nutrient loading in New England estuaries through wastewater management, the cover of impervious surfaces is escalating and water quality continues to decline in most coastal areas (Bricker et al. 2007).

Denitrification and nitrogen storage in salt marshes reduce estuarine nutrient loading, protecting seagrass ecosystems (Valiela \& Cole 2002) and reducing the frequency of hypoxic events and macroalgal blooms
(Valiela et al. 1997). This ecosystem service, however, comes at a cost to salt marsh health and function. Anthropogenic nutrient loading can cause dramatic shifts in the community structure of salt marshes, which have historically been nitrogen-limited. Nitrogen enrichment can increase the aboveground productivity of salt marsh plants (Valiela \& Teal 1974, Levine et al. 1998). But high levels of eutrophication can trigger consumer control by insects leading to reduced aboveground productivity (Bertness et al. 2008) and can reduce belowground biomass allocation and organic matter accumulation (Turner et al. 2009). Nitrogen enrichment reduces belowground competition for nutrients, favoring large aboveground biomass producers that win competition for light, stimulating the shoreward creep of cordgrass (Levine et al. 1998) and the seaward invasion of the common reed Phragmites australis (Bertness et al. 2002).

The invasion and spread of the exotic genotype of Phragmites australis (Saltonstall 2002) has caused some of the most conspicuous changes to New England salt marshes in the last century (Fig. 3; Chambers et al. 1999). $P$. australis spreads rapidly, facilitated by freshwater runoff, nutrients, and disturbance (Minchinton 2002, Silliman \& Bertness 2004), competitively excluding other salt marsh plants and forming a dense monoculture (Minchinton et al. 2006) that raises the marsh platform by increasing sedimentation and litter deposition, and lowers the water table by wicking away water through transpiration (Rooth \& Stevenson 2000). While some salt marsh services such as carbon, nutrient, and pollutant sequestration are maximized in $P$. australis invaded marshes (Weis \& Weis 2003, 2004, Hershner \& Havens 2008), P. australis dominance causes a major shift in salt marsh structure and geomorphology, and drives the loss of plant diversity and the native plant assemblage (Silliman \& Bertness 2004, Meyerson et al. 2009). P. australis invasion of New England salt marshes is among the most conspicuous consequences of human eutrophication, with a direct causal link to shoreline development (Chambers et al. 1999, Bertness et al. 2002, King et al. 2007). A forested upland buffer that intercepts and processes runoff remains the best way to protect salt marshes from upland eutrophication and $P$. australis takeover (Bertness et al. 2009b).

\section{SALT MARSH DIE-OFF}

The unexpected die-off of salt marsh vegetation is an emerging disturbance in New England salt marshes (Fig. 4). Salt marsh die-offs have become epidemic throughout the western Atlantic, and human perturbations of food webs have been identified as the cause of 


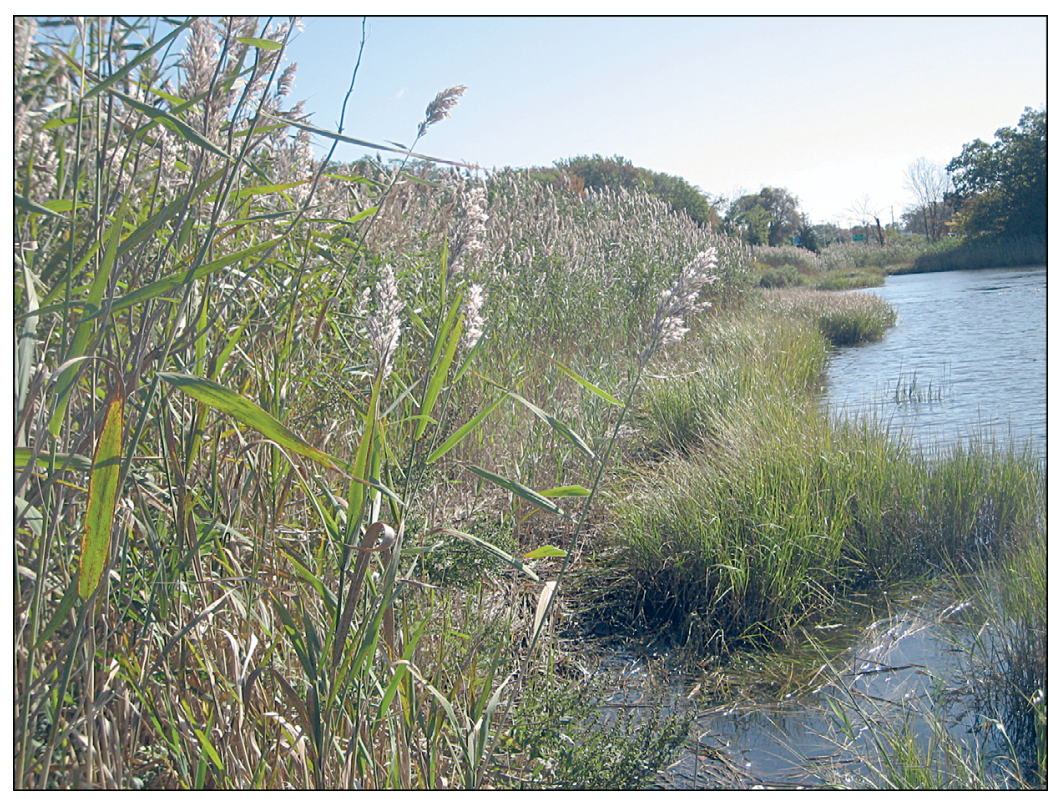

Fig. 3. Phragmites australis in a marsh on the Palmer River in Rehoboth, MA

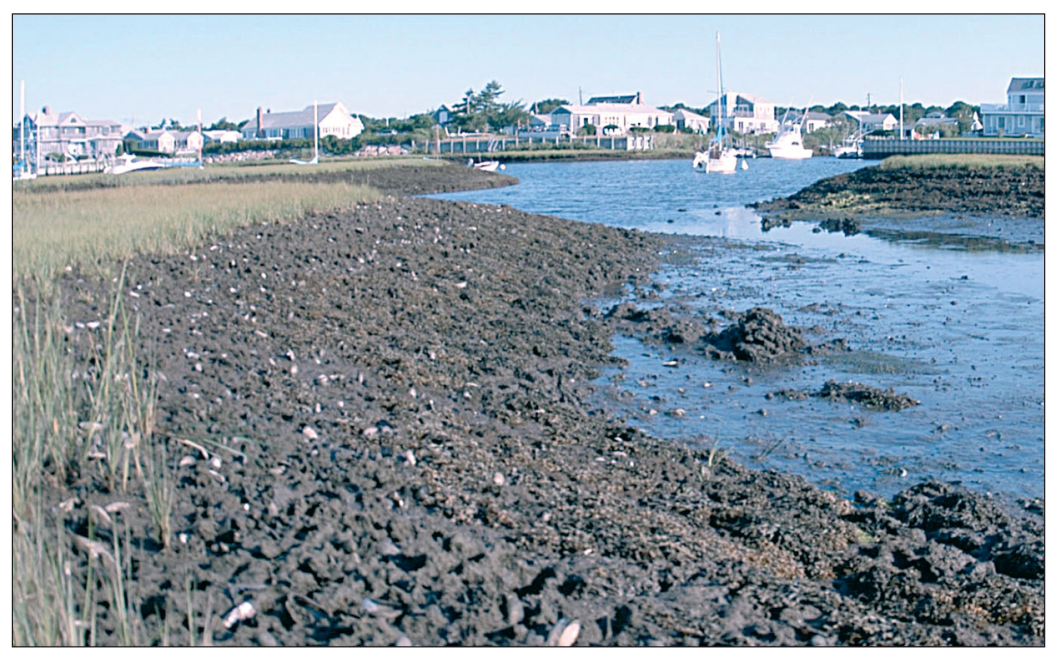

Fig. 4. Crab herbivory driven die-off on creek banks in West Dennis, MA tion in the extent of die-off (Holdredge et al. 2009). Current evidence suggests that the increase in herbivory by $S$. reticulatum generating these die-offs is being driven by overfishing and the release of $S$. reticulatum populations from predation by recreationally fished species (A. H. Altieri et al. unpubl.). On Cape Cod, Narragansett Bay, and Long Island Sound marshes, these die-offs are closely associated with heavily fished areas around marinas, boat ramps, and population centers, and are facilitated by mosquito and drainage ditches, which provide stable burrowing habitats with low burrow maintenance costs (Bertness et al. 2009a).

These die-offs are particularly troubling because they attack cordgrass on the seaward edge of marshes, the habitat that is most critical to the growth and maintenance of marsh ecosystems. Additionally, through negative feedbacks (e.g. hypersaline, anoxic, and sediment starved peat), the denuding of marsh soils prevents or slows the recovery of vegetation (Bertness \& Silliman 2008). Without vegetation, the ecosystem services provided by salt marshes are limited or lost altogether, and the sedimentary foundation of the marsh can erode away. On Cape Cod, die-off areas are expanding at a rate of $>10 \%$ per yr (Holdredge et al. 2009) and are triggering creek widening and marsh loss (Smith 2009).

\section{SEA LEVEL RISE}

Compounding the loss of creekbank cordgrass, sea level rise in New England has accelerated during the last these events (Bertness \& Silliman 2008). Reports of dieoff in New England marshes emerged on Cape Cod in the summer of 2002 (Smith 2006). Field experiments and inter-site correlations between grazing pressure and the occurrence and extent of die-offs have revealed that herbivory by the native, nocturnal crab Sesarma reticulatum on cordgrass is responsible for the Cape Cod marsh die-offs that currently affect nearly $50 \%$ of Cape Cod marsh shorelines (Holdredge et al. 2009). These die-offs are concentrated in cordgrass areas along low marsh creek banks, and crab herbivore intensity explains nearly $80 \%$ of among marsh varia- century from $1.0 \mathrm{~mm} \mathrm{yr}^{-1}$ (1300 to 1850) to $2.4 \mathrm{~mm} \mathrm{yr}^{-1}$ in the 20th century (Donnelly et al. 2004). New England salt marshes have kept pace with sea level rise over the last century (Roman et al. 1997), but they could fall behind with predicted increases in the rate of sea level rise, particularly with the die-off of cordgrass, the foundation species that builds and binds New England salt marsh peat (Kirwan et al. 2008). The IPCC (2007) predicts that the rate of sea level rise may climb as high as $5.9 \mathrm{~mm} \mathrm{yr}^{-1}$ this century, more than double today's rate. Other scientists predict even more extreme rates of sea level rise, up to $16.3 \mathrm{~mm} \mathrm{yr}^{-1}$ (Ver- 
meer \& Rahmstorf 2009), which would submerge even intact salt marshes (Kirwan et al. 2010).

Salt marsh accretion is complex, with feedbacks between sedimentary and biological processes (Morris et al. 2002, FitzGerald et al. 2008). Despite variation in these feedbacks across marsh types, many models of marsh accretion predict future marsh drowning and loss if sea level rise increases as predicted (FitzGerald et al. 2008, but see Kirwan et al. 2010). The peat-based marshes of New England are some of the least likely to keep pace with sea level rise due to low accretion and sediment inputs (FitzGerald et al. 2008, Kirwan et al. 2010). However, the shoreward migration of low marsh vegetation into the high marsh (Donnelly \& Bertness 2001) may allow the persistence of salt marshes as sea level rises, at least where human-built barriers are not encountered. Unfortunately, available data suggests that built barriers are widespread. For example, in Casco Bay, Maine, an area more sparsely populated than most of New England, $20 \%$ percent of the shoreline is armored (Kelley \& Dickson 2000).

In contrast to the negative effect of temperature on waterlogged forb panne areas, sea level rise may drive the expansion of forb pannes (Warren \& Niering 1993). The initiation and expansion of ponds in the high marsh is an additional mechanism of marsh loss attributed to sea level rise in mid-Atlantic salt marshes (Hartig et al. 2002). Where salt marsh areas are converted to unvegetated mudflat or open water, marsh ecosystem services are lost (Craft et al. 2009). Although there are few quantitative estimates of the expected marsh loss in New England due to sea level rise, it is anticipated to be severe. Using current IPCC sea level rise scenarios and a 'sea level affects marshes model' (SLAMM) of salt marsh accretion, Craft et al. (2009) predicted that 20 to $45 \%$ of salt marsh area in a Georgia estuary will be converted to low salinity marsh, tidal flat, or open water by 2100 .

Interactions between sea level rise and other stressors will affect the capacity of marshes to keep pace with sea level rise. Marsh accretion models have shown that vegetation loss combined with sea level rise can lead to permanent marsh loss (Kirwan et al. 2008). Recent marsh loss on Cape Cod suggests that sea level rise and salt marsh die-off are already rapidly converting low marsh to open water without compensatory gains of marsh habitat at the terrestrial border (Smith 2009). Where plant canopies remain intact, temperature increase and sea level rise stressors may counteract one another: temperature-driven stimulation of plant productivity can increase accretion and slow or prevent marsh drowning by sea level rise (Kirwan et al. 2009). Climate warming also reduces forb panne areas whereas sea level rise expands pannes, potentially canceling out or creating lags in panne dynamics.

\section{ST CENTURY CHALLENGES FOR NEW ENGLAND SALT MARSHES}

Accelerating human impacts are overwhelming salt marsh development and recovery by altering inundation regimes and the presence, identity, and productivity of salt marsh foundation species. Despite the cessation of land conversion and the implementation of conservation efforts focused on coastal wetlands, larger-scale human impacts continue to degrade New England salt marshes and could override their historic resilience. The likelihood of habitat loss due to accelerated sea level rise and its interactions with other stressors, particularly salt marsh die-off, are the new prism through which all salt marsh conservation measures must be evaluated.

Salt marsh conservation strategies need to focus on preserving resilience. Dynamic feedback processes, such as the submergence-productivity loop (Morris et al. 2002), are a natural way that salt marshes can maintain development despite sea level rise, whereas shorelines hardened by seawalls and restricted tidal regimes limit the capacity of salt marshes to respond. 'Soft' alternatives to hardened shorelines, such as the reestablishment of an intertidal buffer zone between the sea and relocated human communities (Pethick 2002) and 'living shoreline' restorations of ecosystem engineers like salt marsh grasses or oysters to prevent erosion (Swann 2008) facilitate coastal habitat retention using the natural resilience of shoreline habitats to protect property and human communities (Gedan et al. 2011). For example, in Long Island, NY, The Nature Conservancy is to working to conserve the dynamism of the coastline by using digital elevation, sea level rise, and salt marsh accretion models to identify barriers to marsh migration and quantifying the economic consequences of inaction (The Nature Conservancy 2010). Conservation of critical foundation species such as cordgrass can help ensure that salt marshes retain the capacity to respond to global change. Protecting salt marsh foundation species will require acknowledging the linkage between overfishing and salt marsh dieoffs, to minimize the predator depletion that can trigger herbivore-driven salt marsh die-off (Bertness \& Silliman 2008). Since the predominant paradigm shaping management decisions has been that salt marsh ecosystems are primarily controlled by physical rather than biotic forces, this will be difficult to accomplish. As we have presented, physical and biotic factors interact to shape salt marsh plant communities and they must be given equal attention by managers. The rapid rate at which herbivore driven die-offs have impacted marshes (affecting $>50 \%$ of Cape Cod marsh shorelines in only $30 \mathrm{yr}$; Holdredge et al. 2009), however, makes this shift in management philosophy urgent. 

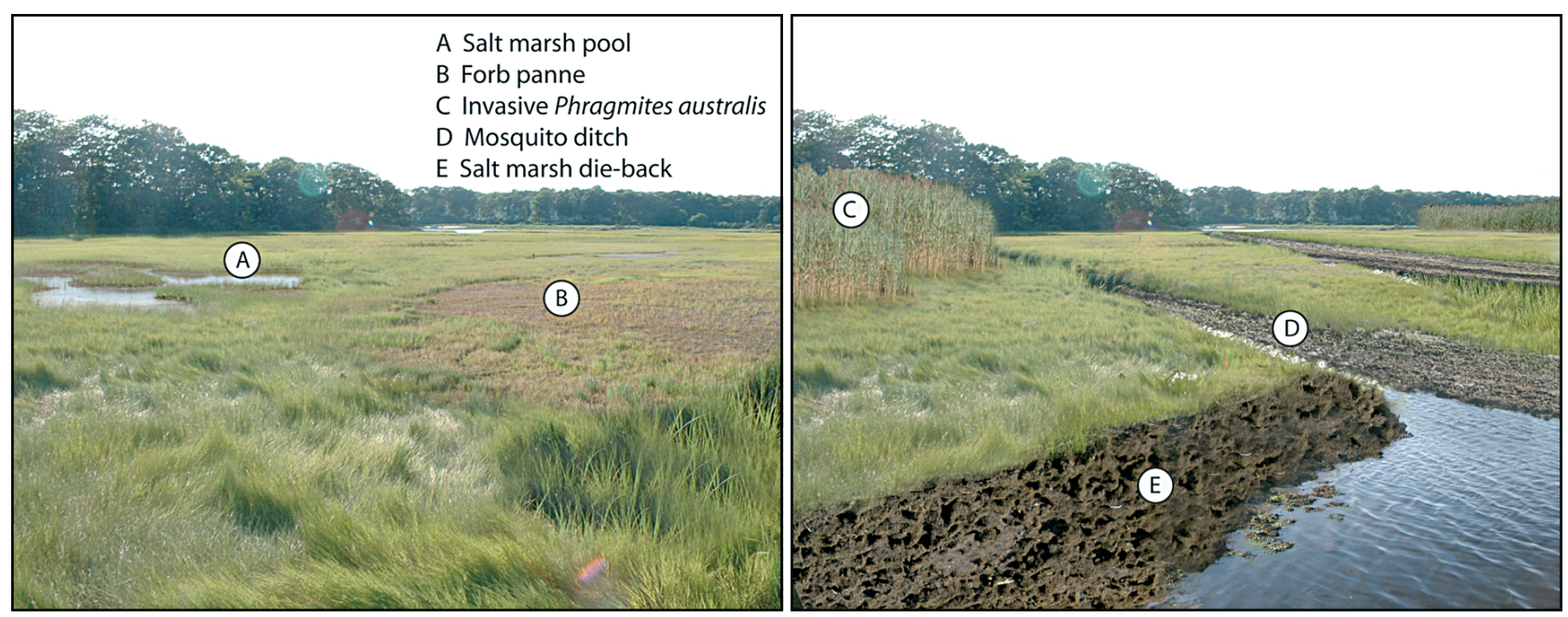

Fig. 5. Representations of a pre-impact New England salt marsh (left), with (A) salt marsh pool and (B) forb panne features, and a heavily impacted New England salt marsh (right) featuring (C) invasive Phragmites australis, (D) mosquito ditches, and (E) salt marsh die-back. The 2 landscapes were digitally constructed to emphasize labeled features. Graphic by Francisco JuradoEmery and Keryn Gedan

Managing for marsh persistence, resilience, and ecosystem services may, in some cases, conflict with other management goals, such as conserving biodiversity. For example, Phragmites australis invasion increases accretion rates and reduces marsh drowning. Eutrophication and ditching to increase $P$. australis dominance could be an answer to managing New England salt marshes to keep pace with sea-level rise and to preserve shoreline buffering and nutrient processing services. However, this would reduce native plant diversity and nursery ground function since $P$. australis eliminates the waterlogged areas and high marsh pools that play a large role in the nursery function of marshes, but would maximize many other ecosystem services provided by New England salt marshes (Hershner \& Havens 2008). Confronting these difficult decisions and tradeoffs will be unavoidable in the future conservation of New England salt marshes. Current management approaches, such as mosquito control methods that involve plugging drainage ditches and constructing ponds to create fish reservoirs (JamesPirri et al. 2008), may benefit wading birds in the short term, but will likely increase the vulnerability of marshes to sea level rise drowning over the long term.

Since New England salt marshes already look different than they did 300 yr ago (Fig. 5), and their historic resilience has been compromised by emerging anthropogenic threats, they should be actively managed in order for continued provision of ecosystem services in the face of global change. The challenge for marsh conservation is to develop adaptive management strategies to respond to local, regional, and global threats that are based on our mechanistic understanding of salt marsh ecosystem dynamics.
Acknowledgements. Open Access for the Theme Section on Coastal Zone Management is sponsored by the Marine Alliance for Science and Technology for Scotland (MASTS) Coastal Zone Joint Research Theme.

\section{LITERATURE CITED}

Bannon RO, Roman CT (2008) Using stable isotopes to monitor anthropogenic nitrogen inputs to estuaries. Ecol Appl 18:22-30

Bertness MD (1991) Interspecific interactions among high marsh perennials in a New England salt marsh. Ecology 72:125-137

Bertness MD, Silliman BR (2008) Consumer control of salt marshes driven by human disturbance. Conserv Biol 22: 618-623

Bertness MD, Ewanchuk PJ, Silliman BR (2002) Anthropogenic modification of New England salt marsh landscapes. Proc Natl Acad Sci USA 99:1395-1398

Bertness MD, Crain CM, Holdredge C, Sala N (2008) Eutrophication and consumer control of New England salt marsh primary productivity. Conserv Biol 22:131-139

Bertness MD, Holdredge C, Altieri AH (2009a) Substrate mediates consumer control of salt marsh cordgrass on Cape Cod, New England. Ecology 90:2108-2117

Bertness MD, Silliman BR, Holdredge C (2009b) Shoreline development and the future of New England salt marsh landscapes. In: Silliman BR, Grosholz ED, Bertness MD (eds) Human impacts on salt marshes: a global perspective. University of California Press, Los Angeles, CA, p 137-148

Boesch DF, Turner RE (1984) Dependence of fishery species on salt marshes: the role of food and refuge. Estuaries 7: 460-468

Bricker SB, Longstaff B, Dennison W, Jones A, Boicourt K, Wicks C, Woerner J (2007) Effects of nutrient enrichment in the nation's estuaries: a decade of change. National Centers for Coastal Ocean Science, Silver Spring, MD

Bromberg K, Bertness MD (2005) Reconstructing New England salt marsh losses using historical maps. Estuaries 28: 823-832 
Chambers RM, Meyerson LA, Saltonstall K (1999) Expansion of Phragmites australis into tidal wetlands of North America. Aquat Bot 64:261-273

Chapman VJ (1940) Succession on the New England salt marshes. Ecology 21:279-282

Chmura GL, Anisfeld SC, Cahoon DR, Lynch JC (2003) Global carbon sequestration in tidal, saline wetland soils. Global Biogeochem Cycles 17:1111-1133

Clements FE (1916) Plant succession: an analysis of the development of vegetation, Publication No. 242. Carnegie Institution of Washington, Washington, DC

> Costanza R, Perez-Maqueo O, Martinez ML, Sutton P, Anderson SJ, Mulder K (2008) The value of coastal wetlands for hurricane protection. Ambio 37:241-248

Craft C, Clough J, Ehman J, Joye S and others (2009) Forecasting the effects of accelerated sea-level rise on tidal marsh ecosystem services. Front Ecol Environ 7:73-78

Crain CM, Gedan KB, Dionne M (2009) Tidal restrictions and mosquito ditches in New England marshes. In: Silliman BR, Grosholz ED, Bertness MD (eds) Human impacts on salt marshes: a global perspective. University of California Press, Los Angeles, CA, p 149-169

> Donnelly JP, Bertness MD (2001) Rapid shoreward encroachment of salt marsh cordgrass in response to accelerated sea-level rise. Proc Natl Acad Sci USA 98:14218-14223

> Donnelly JP, Smith Bryant S, Butler J, Dowling J and others (2001) $700 \mathrm{yr}$ sedimentary record of intense hurricane landfalls in southern New England. Geol Soc Am Bull 113: 714-727

> Donnelly JP, Cleary P, Newby P, Ettinger R (2004) Coupling instrumental and geological records of sea-level change: evidence from southern New England of an increase in the rate of sea-level rise in the late 19th century. Geophys Res Lett 31:L05203 doi:10.1029/2003GL018933

Erickson JE, Megonigal JP, Peresta G, Drake BG (2007) Salinity and sea level mediate elevated $\mathrm{CO}_{2}$ effects on $\mathrm{C}_{3}-\mathrm{C}_{4}$ plant interactions and tissue nitrogen in a Chesapeake Bay tidal wetland. Glob Change Biol 13:202-215

> Ewanchuk PJ, Bertness MD (2004a) The role of waterlogging in maintaining forb pannes in northern New England salt marshes. Ecology 85:1568-1574

Ewanchuk PJ, Bertness MD (2004b) Structure and organization of a northern New England salt marsh plant community. J Ecol 92:72-85

FitzGerald DM, Fenster MS, Argow BA, Buynevich IV (2008) Coastal impacts due to sea-level rise. Annu Rev Earth Planet Sci 36:601-647

Gedan KB (2009) Human impacts in New England salt marshes: past, present, and future. PhD thesis, Brown University, Providence, RI

Gedan KB, Bertness MD (2009) Experimental warming causes rapid loss of plant diversity in New England salt marshes. Ecol Lett 12:842-848

Gedan KB, Bertness MD (2010) How will warming affect the salt marsh foundation species Spartina patens and its ecological role? Oecologia 164:479-487

> Gedan KB, Silliman BR (2009) Patterns of salt marsh loss within coastal regions of North America: presettlement to present. In: Silliman BR, Grosholz ED, Bertness MD (eds) Human impacts on salt marshes: a global perspective. University of California Press, Los Angeles, CA, p 253-265

Gedan KB, Silliman BR, Bertness MD (2009) Centuries of human-driven change in salt marsh ecosystems. Annu Rev Mar Sci 1:117-141

Gedan KB, Kirwan ML, Wolanski E, Barbier EB, Silliman BR (2011) The present and future role of coastal wetland vegetation in protecting shorelines: answering recent chal- lenges to the paradigm. Clim Change 106:7-29

Hartig EK, Gornitz V, Kolker A, Mushacke F, Fallon D (2002) Anthropogenic and climate-change impacts on salt marshes of Jamaica Bay, New York City. Wetlands 22:71-89

Hatvany MG (2003) Marshlands: four centuries of environmental change on the shores of the St. Lawrence. Les Presses de l'Universite Laval, Quebec

Hayhoe K, Wake CP, Huntington TG, Luo L and others (2006) Past and future changes in climate and hydrological indicators in the U.S. Northeast. Clim Dyn 28:381-407

> Hershner C, Havens KJ (2008) Managing invasive aquatic plants in a changing system: strategic consideration of ecosystem services. Conserv Biol 22:544-550

> Holdredge C, Bertness MD, Altieri A (2009) Role of crab herbivory in die-off of New England salt marshes. Conserv Biol 23:672-679

IPCC (2007) Climate change 2007: the physical science basis. Cambridge University Press, New York, NY

Jackson JBC, Kirby MX, Berger WH, Bjorndal KA and others (2001) Historical overfishing and the recent collapse of coastal ecosystems. Science 293:629-638

James-Pirri MJ, Erwin RM, Prosser DJ (2008) US Fish and Wildlife Service (region 5) salt marsh study, 2001 to 2006: an assessment of hydrologic alterations on salt marsh ecosystems along the Atlantic Coast. U.S. Fish and Wildlife Service, Newington, NH

Kelley JT, Dickson SM (2000) Low-cost bluff-stability mapping in coastal Maine: providing geological hazard information without alarming the public. Env Geosci 7:46-56

King RS, Deluca WV, Whigham D, Marra PP (2007) Threshold effects of coastal urbanization on Phragmites australis (common reed) abundance and foliar nitrogen in Chesapeake Bay. Estuaries Coasts 30:469-481

$>$ Kirwan ML, Murray AB, Boyd WS (2008) Temporary vegetation disturbance as an explanation for permanent loss of tidal wetlands. Geophys Res Lett 35:L05403 doi:10.1029/ 2007GL032681

> Kirwan ML, Guntenspergen GR, Morris JT (2009) Latitudinal trends in Spartina alterniflora productivity and the response of coastal marshes to global change. Glob Change Biol 15:1982-1989

Kirwan ML, Guntenspergen GR, D'Alpaos A, Morris JT, Mudd SM, Temmerman S (2010) Limits on the adaptability of coastal marshes to rising sea level. Geophys Res Lett 37:L23401-L23405 doi:10.1029/2010GL045489

Kirwan ML, Murray AB, Donnelly JP, Corbett DR (2011) Rapid wetland expansion during European settlement and its implication for marsh survival under modern sediment delivery rates. Geology 39:507-510

> Levine JM, Brewer JS, Bertness MD (1998) Nutrients, competition and plant zonation in a New England salt marsh. J Ecol 86:285-292

Lotze HK, Lenihan HS, Bourque BJ, Bradbury RH and others (2006) Depletion, degradation, and recovery potential of estuaries and coastal seas. Science 312:1806-1809

Meyerson LA, Saltonstall K, Chambers RM (2009) Phragmites australis in eastern North America: a historical and ecological perspective. In: Silliman BR, Grosholz ED, Bertness MD (eds) Human impacts on salt marshes: a global perspective. University of California Press, Los Angeles, CA, p 57-82

Minchinton TE (2002) Disturbance by wrack facilitates spread of Phragmites australis in a coastal marsh. J Exp Mar Biol Ecol 281:89-107

Minchinton TE, Simpson JC, Bertness MD (2006) Mechanisms of exclusion of native coastal marsh plants by an invasive grass. J Ecol 94:342-354 
Morris JT, Sundareshwar PV, Nietch CT, Kjerfve B, Cahoon DR (2002) Responses of coastal wetlands to rising sea level. Ecology 83:2869-2877

Niering WA, Warren RS (1980) Vegetation patterns and processes in New England salt marshes. Bioscience 30: 301-307

Niering WA, Warren RS, Weymouth CG (1977) Our dynamic tidal marshes: vegetation changes as revealed by peat analysis. Connecticut Arboret Bull 22:2-12

Pethick J (2002) Estuarine and tidal wetland restoration in the United Kingdom: policy versus practice. Restor Ecol 10: 431-437

Redfield AC (1965) Ontogeny of a salt marsh estuary. Science 147:50-55

Roman CT, Peck JA, Allen JR, King JW, Appleby PG (1997) Accretion of a New England (USA) salt marsh in response to inlet migration, storms, and sea-level rise. Estuar Coast Shelf Sci 45:717-727

Rooth J, Stevenson C (2000) Sediment deposition patterns in Phragmites australis communities: implications for coastal areas threatened by rising sea-level. Wetlands Ecol Manage 8:173-183

Saltonstall K (2002) Cryptic invasion by a non-native genotype of the common reed, Phragmites australis, into North America. Proc Natl Acad Sci USA 99:2445-2449

Silliman BR, Bertness MD (2004) Shoreline development drives invasion of Phragmites australis and the loss of plant diversity on New England salt marshes. Conserv Biol 18: $1424-1434$

Smith SM (2006) Report on salt marsh dieback on Cape Cod. National Park Service, Cape Cod National Seashore, Wellfleet, MA

Smith SM (2009) Multi-decadal changes in salt marshes of Cape Cod, Massachusetts: a photographic analysis of vegetation loss, species shifts, and geomorphic change. Northeast Nat 16:183-208

Swann L (2008) The use of living shorelines to mitigate the effects of storm events on Dauphin Island, Alabama, USA.

Submitted: November 8, 2010; Accepted: Februray 11, 2011
Am Fish Soc Symp 64:47-57

The Nature Conservancy (2010) Coastal Resilience Long Island. www.coastalresilience.org

Turner RE (1976) Geographic variations in salt marsh macrophyte production: a review. Contrib Mar Sci 20:47-68

> Turner RE, Howes BL, Teal JM, Milan CS, Swenson EM, Goehringer-Toner DD (2009) Salt marshes and eutrophication: an unsustainable outcome. Limnol Oceanogr 54: $1634-1642$

UNEP (2006) Marine and coastal ecosystems and human wellbeing: a synthesis report based on the findings of the Millennium Ecosystem Assessment. UNEP

Valiela I, Cole ML (2002) Comparative evidence that salt marshes and mangroves may protect seagrass meadows from land-derived nitrogen loads. Ecosystems 5:92-102

Valiela I, Teal JM (1974) Nutrient limitation in salt marsh vegetation. In: Reimold RJ, Queen WH (eds) Ecology of halophytes. Academic Press, New York, NY, p 547-563

Valiela I, Teal JM (1979) The nitrogen budget of a salt marsh ecosystem. Nature 280:652-656

Valiela I, McClelland J, Hauxwell J, Behr PJ, Hersh D, Foreman K (1997) Macroalgal blooms in shallow estuaries: controls and ecophysiological and ecosystem consequences. Limnol Oceanogr 42:1105-1118

> Vermeer M, Rahmstorf S (2009) Global sea level linked to global temperature. Proc Natl Acad Sci USA 106: 21527-21532

> Warren RS, Niering WA (1993) Vegetation change on a northeast tidal marsh: interaction of sea-level rise and marsh accretion. Ecology 74:96-103

Weis JS, Butler C (2009) Salt marshes: a natural and unnatural history. Rutgers University Press, New Brunswick, NJ

Weis JS, Weis P (2003) Is the invasion of the common reed, Phragmites australis, into tidal marshes of the eastern U.S. an ecological disaster? Mar Pollut Bull 46:816-820

> Weis JS, Weis P (2004) Metal uptake, transport and release by wetland plants: implications for phytoremediation and restoration. Environ Int 30:685-700b

Proofs received from author(s): July 5, 2011 